\section{US National Cancer Institute chief quits}

Washington. Sam Broder, director of the National Cancer Institute (NCI) since 1989, is to leave the institute in April to become research chief at IVAX, a pharmaceutical company based in Miami, Florida. Broder says that he wants to leave the NCI, where he has worked for 22 years, while he is still young enough to pursue a career in the private sector. $\mathrm{He}$ is 49 .

He denied reports that his departure is the result of disagreements with Harold Varmus, director of the National Institutes of Health $(\mathrm{NIH})$, the NCI's parent organization, about a planned restructuring of the institute. "We get along very well," Broder said. "We don't agree on everything - but if everyone always agreed, it would be a sign of a dysfunctional system. You don't want yes-men in high positions at NIH, and Dr Varmus rather enjoys that give and take."

Varmus issued a statement praising Broder's record in research and management at the institute, and thanking him for "advice to me during my first years as director of NIH". With an annual budget of $\$ 2.2$ billion, the NCI is by far the largest component of the NIH, and its director has considerable autonomy.

Broder said his departure was also prompted by frustration with the slow has gotten less". dence in my leadership.' and development. tions are already vacant. pace of decision-making in government. Over the years, he said, "the bureaucracy has gotten worse, and my tolerance of it

$\mathrm{He}$ expressed satisfaction with his achievements during his time as NCI's director. "We promoted the concept that NCI is an organic whole, consisting of basic research, clinical research and the cancer centres. I have strengthened all three in the last six years. "We also won the largest dollar increase in our history in 1992. That was, in part, a vote of confi-

At IVAX - a \$600-million company known best for its generic drugs - Broder will become vice president for research

Broder is widely liked and respected, even by his critics among cancer activists and in Congress. Some now fear a leadership vacuum at $\mathrm{NCI}$, where the deputy directorship and several other senior posi-

A successor will be appointed by President Bill Clinton, presumably in consultation with Varmus and Donna Shalala, the health secretary. The post does not require Senate confirmation, but the administration may still be hard-pressed to fill it before Broder leaves in April.

Colin Macilwain

\section{Newton adds gravitas to new library}

\begin{abstract}
London. This 12-foot high statue of Sir Isaac Newton, plotting the immensity of the Universe with a pair of dividers, will be the first sight to greet visitors entering the grounds of the new British Library in St Pancras in London, when it opens in late 1997.

The statue, which is inspired by William Blake's famous painting of Isaac Newton, will stand on a 12-foot plinth in the Piazza, framed by the main entrance gates. Scottish sculptor Eduardo Paolozzi, who is seen with his statue as it nears completion, was commissioned to make the piece after the architect of the new building, Colin StJohn Wilson, saw a scaled-down model in Paolozzi's studio.
\end{abstract}

Delays in the construction of the building and problems with the project running over budget have attracted criticism. Stephen Dorrell, the secretary of state for national heritage, announced after the budget in November last year that an extra $£ 46$ million would be made available to complete construction by the end of 1996 . Previous estimates put the total cost for the building at $£ \mathbf{4 5 0}$ million.

\section{Nirex to appeal after permission refused for 'rock lab' at Sellafield}

London. Cumbria County Council last month refused planning permission for a $£ 120$-million rock characterization facility (RCF), that the company UK Nirex Ltd wants to build at Sellafield in Cumbria, in northwest England, near the planned site for the United Kingdom's first underground repository for nuclear waste. Nirex says it will appeal against the decision.

Nirex's plans for the RCF - which would be used to study groundwater flow - are backed by the Royal Society. The society recently recommended that the rock laboratory should be built "as soon as is practicable", provided that sufficient information was obtained before the RCF disturbs the area's hydrogeological characteristics (see Nature 372, 309; 1994).

But the decision by Nirex to appeal will almost certainly lead to a public inquiry into the application. The council had already requested a comprehensive inquiry in a letter to John Gummer, the secretary of state for the environment, last August, shortly after it received the application for planning permission - the $\mathrm{RCF}$, it told Gummer "raises matters of more than local importance".

The council voted overwhelmingly to reject Nirex's application, at a meeting on 20 December, but Gummer had in any case already instructed the council "not to grant permission on the application without special authorization". Gummer said he needed more time in which to decide whether to call a public inquiry.

Because the council had rejected the application early in the meeting, it did not vote on another motion to defer the application until the government had completed reviews of the nuclear industry and radioactive waste, and until Nirex had obtained more data from existing boreholes around the proposed repository zone. Some observers consider that this voting procedure was abnormal, and that the motions should have been proposed, amended and debated simultaneously.

Nirex says it will appeal as soon as it "gets the relevant papers together". It added that the public inquiry, which will take several months to organize, will probably be able to take into account the conclusions of the government reviews now under way. "The whole thing now will be very timely."

Some observers argue that the application was bound to be rejected because Nirex made it too soon. But Nirex argues that it needs to push ahead with hyrdrogeological investigations, and is continually publishing data from existing boreholes.

Maggie Verrall 